\title{
Integrated Management of Tomato Whitefly Under Greenhouse Conditions
}

\author{
Jonas A. Arnemann ${ }^{1}$, Júlia G. Bevilaqua ${ }^{1}$, Lauro Bernardi ${ }^{2}$, Danielle O. da Rosa ${ }^{2}$, Fábio A. da Encarnação ${ }^{2}$, \\ Henrique Pozebon ${ }^{1}$, Rafael P. Marques ${ }^{1}$, Daniela Moro ${ }^{1}$, Dener Ribas ${ }^{1}$, Leonardo S. Patias ${ }^{1}$, Sarah E. Forgiarini ${ }^{1}$, \\ Guilherme Padilha ${ }^{1}$, João V. L. Campos ${ }^{1}$ \& Alberto Rohrig ${ }^{3}$ \\ ${ }^{1}$ Departament of Crop Protection, Federal University of Santa Maria, Santa Maria, RS, Brazil \\ ${ }^{2}$ Emater/RS-ASCAR, Regional Lajeado, Lajeado, RS, Brazil \\ 317 Valentin Street, Pinheiros Residential, Cruz Alta, RS, Brazil \\ Correspondence: Jonas A. Arnemann, Departament of Crop Protection, Federal University of Santa Maria \\ (UFSM), Avenida Roraima 1000, Santa Maria, Rio Grande do Sul, 97105-900, Brazil. E-mail: \\ jonasarnemann@gmail.com
}

Received: January 16, 2019

Accepted: February 28, $2019 \quad$ Online Published: April 15, 2019

doi:10.5539/jas.v11n5p443

URL: https://doi.org/10.5539/jas.v11n5p443

\begin{abstract}
The whitefly Bemisia tabaci (Gennadius, 1889) is a major pest species in many agricultural crops worldwide. Growers from the Vale do Caí region, in Southern Brazil (Rio Grande do Sul state) have been facing severe economic losses due to the increasing damages caused by this sucking insect in their horticultural crops. Small-scale farming in the Vale do Caí region relies heavily on horticulture, with many families involved in the activity and a consumer market spread throughout the whole state. Virus transmission and other damages inflicted by $B$. tabaci are especially harmful to tomato plants, and the managing of the pest currently demands two thirds of all chemical insecticides used in the region. While chemical control remains the main strategy for whitefly management on tomato crops, control failures and lack of updated information have led tomato growers to raise the number of sprays per crop cycle, with selection of resistant populations and harmful effects on the environment as consequent risks. The aim of this work was to evaluate chemical compounds and bioinsecticides in the control of $B$. tabaci nymphs and adults on tomato plants grown in two different greenhouses and under natural infestation conditions. The most efficient treatment for the control of $B$. tabaci adults was cyantraniliprole + lambda-cyhalothrin $\left(50+30\right.$ g a.i. $\left.\mathrm{ha}^{-1}\right)$ with $64 \%$ of average control efficiency. As for nymph control, the most efficient treatment was the Embrapa formula, a bioinsecticide composed of $0.5 \%$ flaxseed oil + $0.5 \%$ neutral detergent $+0.3 \%$ sodium bicarbonate, which resulted in $72 \%$ of whitefly control in average.
\end{abstract}

Keywords: Bemisia tabaci, bioinsecticides, integrated pest management, Solanum lycopersicum

\section{Introduction}

Bemisia tabaci (Gennadius, 1889) (Hemiptera: Aleyrodidae) comprises a highly adapted and widely dispersed species complex, being considered a major pest in many crops worldwide (Byrne \& Bellows Jr., 1991; Basu, 1995; De Barro, 2000). The damages inflicted by whitefly on its plant hosts result directly from sap sucking and toxin injection, and indirectly from virus transmission and honeydew secretion, which serves as a substrate for the growth of sooty mold fungi upon the leaves (Hirose et al., 2015). B. tabaci is known to serve as vector for around ten percent of all known plant pathogenic viruses (Fauquet et al., 2008). While the term biotype has been commonly used to distinguish whitefly lineages with different behaviors and geographical traits, De Barro et al. (2011) defines B. tabaci as a complex of 11 groups and at least 24 different species, distinguishable only through mitochondrial DNA analysis.

Tomato plants are mainly damaged by $B$. tabaci due to virus transmission, such as the Tomate yellow leaf curl disease (TYLCD) (Cohen \& Antignus, 1994; Jones, 2003), with yield losses mounting up to 70\% (Villas Boas et al., 1997). Additionally, sap sucking by B. tabaci can lead to the death of seedlings, physiological disorder and irregular rippening of the fruits; in cases of high infestation, losses due to these direct damages may reach up to $50 \%$ (Santos, 2008). The Vale do Caí region is an important grower of horticultural crops in the Rio Grande do Sul state (Southern Brazil), with 1624 families directly involved in the activity and a consumer market spread 
throughout the whole state. In the entire region, the total area grown with horticultural crops in 2016 was of 2 538 hectares, with a total production of approximately 92800 tons (Emater/RS-ASCAR, 2017). Nonetheless, growers from Vale do Caí have been facing severe economic losses due to the increasing occurrence of $\mathrm{B}$. tabaci on tomato and other crops and the difficulties involved in controllig this pest, which currently demands $67 \%$ of all insecticides sprayed in the region (Rosa, 2017).

While the use of chemical insecticides remains the most common strategy for whitefly control on tomato crops, the growing scale of the infesting populations suggests that the current programs have not been entirely efficient in the management of this pest. Scarcity of updated information and of technical follow-up have led tomato growers to raise excessively the number of sprays per crop cycle, potentially resulting in harmful effects on the environment such as water and soil contamination and negative impact on non-target organisms, as well as poisoning of farmers and presence of agrochemical residues in food. Furthermore, Bernardi (2016) reported the occurrence of resistant whitefly strains in the municipalities of Boa Vista do Sul, Bom Princípio, Caxias do Sul, Cruzeiro do Sul, Feliz, Flores da Cunha, Lajeado and São Marcos, all of which are located either in the Vale do Caí region or in its vicinities. Therefore, scientific research that supports the definition of an efficient whitefly management program and ensures that this information is taken to the growers and field professionals becomes extremely necessary.

The aim of this work was to evaluate the efficiency of chemical compounds and bioinsecticides in the control of B. tabaci adults and nymphs on tomato plants grown under greenhouse conditions, in two different sites, in order to estabilish the most efficient strategy for whitefly control on tomato crops.

\section{Materials and Methods}

\subsection{Experimental Sites}

The experiments took place from 09/02/2018 to 27/02/2018 in São José do Hortêncio, Rio Grande do Sul, Brazil (29 $31^{\prime} 50^{\prime \prime} \mathrm{S}, 51^{\circ} 14^{\prime} 53^{\prime \prime} \mathrm{W}, 100$ meters a.s.1.), a municipality located in the Vale do Caí region. Meteorological data registered by the INMET (National Meteorological Institute) station of Novo Hamburgo, RS $\left(29^{\circ} 67^{\prime} 42^{\prime \prime}\right.$ S, $51^{\circ} 06^{\prime} 40^{\prime \prime} \mathrm{W}, 23 \mathrm{~m}$ a.s.1.) during the experiment period are provided on Supplementary Table 1. Two greenhouses of different tomato growers and with different infestation levels, located in the same municipality, were chosen as experimental sites. The infestation occurred naturally inside the greenhouses. The greenhouse in Experiment I (29 $31^{\prime} 31^{\prime \prime} \mathrm{S}, 51^{\circ} 17^{\prime} 19^{\prime \prime} \mathrm{W}, 97 \mathrm{~m}$ a.s.1.) was heavily infested with $\mathrm{B}$. tabaci at the time of the treatments spraying (3.2 adults leaflet ${ }^{-1}$ and 45.6 nymphs leaflet $^{-1}$, on average), while the infestation in the

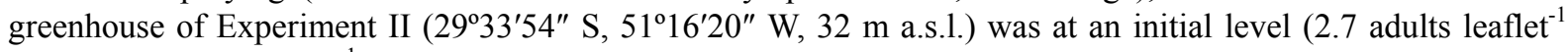
and 10.0 nymphs leaflet $^{-1}$, on average). 
Table 1. Active ingredient, brand name, mode of action and spray doses of the chemical insecticides and bioinsecticides evaluated for the control of Bemisia tabaci on tomato plants under greenhouse conditions. São José do Hortêncio, RS, Brazil

\begin{tabular}{|c|c|c|c|c|c|}
\hline \multirow{2}{*}{ Treatment } & \multirow{2}{*}{ Active ingredient } & \multirow{2}{*}{ Brand name } & \multirow{2}{*}{ Mode of action } & \multicolumn{2}{|c|}{ Dose ha $^{-1}$} \\
\hline & & & & c.p. ${ }^{1}$ & a.i. ${ }^{2}$ \\
\hline $\mathrm{T} 1$ & Untreated control & - & - & - & - \\
\hline $\mathrm{T} 2$ & Acetamiprid + pyriproxyfen & Privilege & $\begin{array}{l}\text { Nicotinic acetylcholine receptor agonists } \\
+ \text { Juvenile hormone mimics }\end{array}$ & 300 & $60+30$ \\
\hline $\mathrm{T} 3$ & Spiromesifene & Oberon & Inhibitors of acetyl CoA carboxylase & 600 & 144 \\
\hline $\mathrm{T} 4$ & Cyantraniliprole & Benevia & Ryanodine receptor modulators & 500 & 50 \\
\hline T5 & Cyantraniliprole + lambda-cyhalothrin & Kaiso + Benevia & $\begin{array}{l}\text { Ryanodine receptor modulators } \\
\text { + Sodium channel modulators }\end{array}$ & $500+120$ & $50+30$ \\
\hline T6 & Acetamiprid + bifenthrin & UPL 138 & $\begin{array}{l}\text { Nicotinic acetylcholine receptor agonists } \\
+ \text { Sodium channel modulators }\end{array}$ & 160 & $40+40$ \\
\hline $\mathrm{T} 7$ & Imidacloprid & Nuprid & Nicotinic acetylcholine receptor agonists & 300 & 210 \\
\hline $\mathrm{T} 8$ & E-coda-oil K ${ }^{3}$ & E-coda-oil K & (Bioinsecticide) & 1.2 & - \\
\hline T9 & Citronella extract & - & (Bioinsecticide) & 1.2 & - \\
\hline $\mathrm{T} 10$ & Embrapa formula $^{4}$ & - & (Bioinsecticide) & - & - \\
\hline $\mathrm{T} 11$ & Pyrolignous extract & - & (Bioinsecticide) & 8 & - \\
\hline $\mathrm{T} 12$ & Beauveria bassiana & Beauve Control & (Bioinsecticide) & 400 & 16 \\
\hline
\end{tabular}

Note. ${ }^{1}$ c.p. $=$ Commercial product $\left(\mathrm{g}\right.$ or $\mathrm{mL}$ hectare $\left.{ }^{-1}\right) .{ }^{2}$ a.i. $=$ Active ingredient $\left(\mathrm{g}\right.$ hectare $\left.{ }^{-1}\right) \cdot{ }^{3}$ E-coda-oil $\mathrm{K}$ is a product imported from Spain, with registration in the Brazilian Ministry for Agriculture, Livestock and Supply (MAPA). ${ }^{4}$ The Embrapa formula is composed of $0.5 \%$ flaxseed oil $+0.5 \%$ neutral detergent $+0.3 \%$ sodium bicarbonate.

\subsection{Treatments}

The choice of treatments was based on the insecticides commonly used by the growers and more recommended by field professionals in the region to control B. tabaci on tomato crops. The treatments composed of chemical and biological insecticides, their respective active ingredients, brand names, modes of action in the insect's body and spray doses are shown on Table 1. In all bioinsecticidal treatments (T8, T9, T10, T11 and T12), 5 ml of pyroligneous extract were added as a $\mathrm{pH}$ reducer, resulting in a spray volume with a $\mathrm{pH}$ of 6.4.

\subsection{Experimental Design}

The experiments were comprised of $15 \mathrm{~m}^{2}$ plots $(3 \mathrm{~m} \times 5 \mathrm{~m})$, with 4 replicates per treatment, in a randomized block design. The sprayings were carried out at the infestation onset, using a $\mathrm{CO}_{2}$-pressurized backpack sprayer, nozzles model TJ60-11003VS, and $400 \mathrm{~L} \mathrm{ha}^{-1}$ of spray volume. On Experiment I, only one spray was made, while Experiment II received two sprays with an interval of 7 days between them.

\subsection{Evaluations}

Evaluations were made at 0, 4, 7, 11 and 14 days after spraying (DAS), for Experiment I; and at 0, 4 and 7 days after the first spraying (DA1S) and 4, 7 and 11 days after the second spraying (DA2S) for Experiment II. In each plot, 10 central leaflets were selected from random tomato plants, in the middle and upper thirds. In the abaxial side of these leaflets, the number of whitefly adults was counted in each evaluation, by slowly turning the leaflet upside down in order to prevent the escape of the insects. To proceed the counting of nymphs, 10 leaflets were collected per plot, from the middle and lower thirds of the plants, for later quantification in laboratory with the aid of a digital magnifying glass model Zeiss Discovery V12, at the Integrated Pest Management Laboratory, Federal University of Santa Maria (LabMIP-UFSM), Brazil.

\subsection{Statistical Analysis}

Control efficiency for each insecticide treatment was assessed through the equation of Abbott (1925), with the obtained values being submitted to variance analysis (ANOVA) and to the mean separation test of Scott-Knott (P $\leq 0.05)$. All statistical analyses were carried out using the softwares Microsoft Excel ${ }^{\circledR}(2010)$ and $\operatorname{SAS}^{\circledR}(2002)$. 


\section{Results and Discussion}

\subsection{Experiment I}

Whitefly infestation inside the greenhouse on Experiment I was at a high level by the time of spraying, with an average of 3.2 adults leaflet ${ }^{-1}$ and 45.6 nymphs leaflet $^{-1}$ (Table 2). While there is no defined economic injury level for $B$. tabaci on tomato crops to-date, the low control efficiency provided by all treatments in the first evaluation (4 DAS) suggests that the threshold for control decision-making must be below this infestation level. Accordingly, Lima et al. (2018) sets the economic injury levels for B. tabaci on watermelon crops between 0.13 and 0.52 adults leaf ${ }^{1}$ at the vegetative stage of the plants, and 0.44 to 1.69 during the reproductive stage. Naranjo, Chu and Henneberry (1996) suggest a higher economic injury level for whitefly on cotton crops, varying around 10 adults leaf ${ }^{1}$, but never above 5 nymphs $\mathrm{cm}^{-2}$-which is considerably below the number of nymphs found at the spray moment in the present work.

Table 2. Mean number (M) of living adults and nymphs leaflet ${ }^{-1}$ and control efficiency (CE\%) of Bemisia tabaci adults and nymphs in response to the treatments sprayed on greenhouse tomatoes in Experiment I. São José do Hortêncio, RS, Brazil

\begin{tabular}{|c|c|c|c|c|c|c|c|c|c|c|}
\hline \multirow{2}{*}{ Treataments } & \multirow{2}{*}{$\begin{array}{l}\text { 0 DAS } \\
\mathbf{M}\end{array}$} & \multicolumn{2}{|c|}{4 DAS } & \multicolumn{2}{|c|}{7 DAS } & \multicolumn{2}{|c|}{11 DAS } & \multicolumn{2}{|c|}{14 DAS } & \multirow{2}{*}{ - Mean CE\% } \\
\hline & & $\mathbf{M}$ & CE\% & $\mathbf{M}$ & CE\% & $\mathbf{M}$ & CE\% & $\mathbf{M}$ & CE\% & \\
\hline \multicolumn{11}{|l|}{ Adults } \\
\hline Untreated control & 3.2 & $1.2 \mathrm{c}^{2}$ & - & $6.8 \mathrm{a}$ & - & $4.2 \mathrm{~b}$ & - & $6.6 \mathrm{a}$ & - & - \\
\hline Acetamiprid + pyriproxyfen & 3.2 & $4.0 \mathrm{a}$ & 0.00 & $3.6 \mathrm{a}$ & 47.06 & $11.4 \mathrm{a}$ & 0.00 & $5.2 \mathrm{a}$ & 21.21 & 17.07 \\
\hline Spiromesifene & 3.2 & $4.6 \mathrm{a}$ & 0.00 & $3.6 \mathrm{a}$ & 47.06 & $6.4 \mathrm{a}$ & 0.00 & $6.4 \mathrm{a}$ & 3.03 & 12.52 \\
\hline Cyantraniliprole & 3.2 & $6.6 \mathrm{a}$ & 0.00 & $3.0 \mathrm{a}$ & 55.88 & $8.0 \mathrm{a}$ & 0.00 & $4.8 \mathrm{a}$ & 27.27 & 20.79 \\
\hline Cyantraniliprole + lambda-cyhalothrin & 3.2 & $2.2 \mathrm{~b}$ & 0.00 & $2.0 \mathrm{a}$ & 70.59 & $8.4 \mathrm{a}$ & 0.00 & $6.4 \mathrm{a}$ & 3.03 & 18.40 \\
\hline Acetamiprid + bifenthrin & 3.2 & $4.8 \mathrm{a}$ & 0.00 & $2.4 \mathrm{a}$ & 64.71 & $9.4 \mathrm{a}$ & 0.00 & $2.2 \mathrm{a}$ & 66.67 & 32.84 \\
\hline Imidacloprid & 3.2 & $2.4 \mathrm{~b}$ & 0.00 & $2.4 \mathrm{a}$ & 64.71 & $6.4 \mathrm{a}$ & 0.00 & $7.0 \mathrm{a}$ & 0.00 & 16.18 \\
\hline E-coda-oil K & 3.2 & $4.2 \mathrm{a}$ & 0.00 & $3.8 \mathrm{a}$ & 44.12 & $6.8 \mathrm{a}$ & 0.00 & $8.8 \mathrm{a}$ & 0.00 & 11.03 \\
\hline Citronella extract & 3.2 & $3.4 \mathrm{a}$ & 0.00 & $3.6 \mathrm{a}$ & 47.06 & $5.8 \mathrm{~b}$ & 0.00 & $5.4 \mathrm{a}$ & 18.18 & 16.31 \\
\hline Embrapa formula & 3.2 & $2.2 \mathrm{~b}$ & 0.00 & $3.2 \mathrm{a}$ & 52.94 & $4.6 \mathrm{~b}$ & 0.00 & $10.8 \mathrm{a}$ & 0.00 & 13.24 \\
\hline Pyrolignous extract & 3.2 & $2.6 \mathrm{~b}$ & 0.00 & $3.6 \mathrm{a}$ & 47.06 & $6.6 \mathrm{a}$ & 0.00 & $7.6 \mathrm{a}$ & 0.00 & 11.76 \\
\hline Beauveria bassiana & 3.2 & $0.4 \mathrm{c}$ & 66.67 & $1.8 \mathrm{a}$ & 73.53 & $3.8 \mathrm{~b}$ & 9.52 & $5.8 \mathrm{a}$ & 12.12 & 40.46 \\
\hline $\mathrm{CV}(\%)^{3}$ & - & 32.67 & - & 40.97 & - & 19.47 & - & 74.52 & - & - \\
\hline \multicolumn{11}{|l|}{ Nymphs } \\
\hline Untreated control & 45.6 & $46.5 \mathrm{a}$ & - & $51.2 \mathrm{a}$ & - & $46.1 \mathrm{a}$ & - & $8.6 \mathrm{~b}$ & - & - \\
\hline Acetamiprid + pyriproxyfen & 45.6 & $40.7 \mathrm{a}$ & 12.47 & $78.2 \mathrm{a}$ & 0.00 & $22.0 \mathrm{~b}$ & 52.28 & $38.1 \mathrm{~b}$ & 0.00 & 16.19 \\
\hline Spiromesifene & 45.6 & $50.6 \mathrm{a}$ & 0.00 & $43.3 \mathrm{a}$ & 15.43 & $49.9 \mathrm{a}$ & 0.00 & $81.5 \mathrm{a}$ & 0.00 & 3.86 \\
\hline Cyantraniliprole & 45.6 & $22.7 \mathrm{a}$ & 51.18 & $36.4 \mathrm{a}$ & 28.91 & $39.1 \mathrm{a}$ & 15.18 & $49.2 \mathrm{a}$ & 0.00 & 23.82 \\
\hline Cyantraniliprole + lambda-cyhalothrin & 45.6 & $22.7 \mathrm{a}$ & 51.18 & $33.3 \mathrm{~b}$ & 34.96 & $50.6 \mathrm{a}$ & 0.00 & $34.9 \mathrm{~b}$ & 0.00 & 21.54 \\
\hline Acetamiprid + bifenthrin & 45.6 & $69.5 \mathrm{a}$ & 0.00 & $41.7 \mathrm{a}$ & 18.55 & $47.8 \mathrm{a}$ & 0.00 & $23.7 \mathrm{~b}$ & 0.00 & 4.64 \\
\hline Imidacloprid & 45.6 & $41.4 \mathrm{a}$ & 10.97 & $28.4 \mathrm{~b}$ & 44.53 & $45.2 \mathrm{a}$ & 1.95 & $58.2 \mathrm{a}$ & 0.00 & 14.36 \\
\hline E-coda-oil K & 45.6 & $30.6 \mathrm{a}$ & 34.19 & $26.7 \mathrm{~b}$ & 47.85 & $42.2 \mathrm{a}$ & 8.46 & $38.7 \mathrm{~b}$ & 0.00 & 22.63 \\
\hline Citronella extract & 45.6 & $67.3 \mathrm{a}$ & 0.00 & -4 & -4 & $34.4 \mathrm{a}$ & 25.38 & $81.6 \mathrm{a}$ & 0.00 & 8.46 \\
\hline Embrapa formula & 45.6 & $36.3 \mathrm{a}$ & 21.94 & $52.8 \mathrm{a}$ & 0.00 & $22.1 \mathrm{~b}$ & 52.06 & $58.5 \mathrm{a}$ & 0.00 & 18.50 \\
\hline Pyrolignous extract & 45.6 & $27.6 \mathrm{a}$ & 40.65 & $15.9 \mathrm{~b}$ & 68.95 & $23.4 \mathrm{~b}$ & 49.24 & $20,2 \mathrm{~b}$ & 0.00 & 39.71 \\
\hline Beauveria bassiana & 45.6 & $47.5 \mathrm{a}$ & 0.00 & $9.3 \mathrm{~b}$ & 81.84 & $6.2 \mathrm{~b}$ & 86.55 & $7.5 \mathrm{~b}$ & 12.79 & 45.29 \\
\hline $\mathrm{CV}(\%)^{3}$ & - & 88.71 & - & 122.84 & - & 89.31 & - & 118.99 & - & $\begin{array}{ll}-- \\
-\end{array}$ \\
\hline
\end{tabular}

Note. ${ }^{1}$ DAS $=$ Days after spraying. ${ }^{2}$ Means followed by the same letter do not differ among themselves by the Scott-Knott test $(\mathrm{P} \leq 0.05) .{ }^{3} \mathrm{CV}(\%)=$ Coefficient of variation.

All treatments, except for T12 (Beauveria bassiana $16 \mathrm{~g} \mathrm{ha}^{-1}$ ), caused no reduction of $B$. tabaci adults at the first evaluation (4 DAS). Even the treatments including pyrethroid insecticides (T5 and T6, with the pyrethroids lambda-cyhalothryn $30 \mathrm{~g} \mathrm{ha}^{-1}$ and bifenthrin $40 \mathrm{~g} \mathrm{ha}^{-1}$, respectively), which are known to cause a fast knockdown effect on insects due to their mode of action (sodium channel modulators; see Table 1), presented control efficiency equal to zero at this evaluation. Tretatment T12 (Beauveria bassiana $16 \mathrm{~g} \mathrm{ha}^{-1}$ ), however, provided $66 \%$ of whitefly control at 4 DAS, reducing the population to 0.4 adults leaflet $^{-1}$. B. bassiana is an 
entomopathogenic fungi whose spores infect the insect by direct contact, covering the host's body with a layer of white mold that produces more infective spores (Groden, 1999). Thus, the high population of whitefly adults present at the spraying moment may have enhanced the performance of this bioinsecticide by favouring spore dispersion, while reducing the efficacy of other treatments due to their different modes of action.

Overall, the highest reduction of $B$. tabaci adults was obtained with treatment T12 (Beauveria bassiana $16 \mathrm{~g}$ $\mathrm{ha}^{-1}$ ) followed by T6 (acetamiprid + bifenthrin $40+40 \mathrm{~g} \mathrm{ha}^{-1}$ ), with average control means of $40 \%$ and $33 \%$, respectively (Table 2). Tretament T12 showed the best knockdown effect, reducing the infesting population to 0.4 adults leaflet ${ }^{-1}$ at the first evaluation (4 DAS); treatment $\mathrm{T} 6$, on the other hand, present the longest residual control effect, keeping the infestation level at 2.2 adults leaflet $^{-1}$ at the last evaluation (14 DAS). While the final means of control efficiency may be considered extremely low, the occurrence of control efficiencies equal to zero for almost all treatments in two of the four evaluations (4 DAS and 11 DAS) may have overeduced the average means; nonetheless, the values are well representative of the difficulty in controlling whiteflies at high infestation levels with only one spray, regardless of the insecticide used.

Concerning the control of whitefly nymphs, treatment T12 (Beauveria bassiana $16 \mathrm{~g} \mathrm{ha}^{-1}$ ) was also the most efficient in reducing the number of individuals, reaching $86 \%$ of control at 11 DAS and keeping the infestation level on 6.2 nymphs leaflet $^{-1}$; for comparison, treatment T5 (cyantraniliprole + lambda-cyhalothrin $50+30 \mathrm{~g} \mathrm{ha}^{-1}$ ) presented 50 nymphs leaflet ${ }^{-1}$ at this evaluation. Treatment T11 (pyroligneous extract) presented the second highest efficiency, with an average control mean of $40 \%$. This bioinsecticide is obtained from the condensed smoke of burning wood in charcoal mines, and is commonly used by organic growers as pest killer and fertilizer. Azevedo, Guimarães, Braga Sobrinho, and Lima (2005) attested a control efficiency of $67.35 \%$ for B. tabaci nymphs using the pyroligneous extract on watermelon; the same study stated that insecticides based on entomopathogenic fungi, such as B. bassiana, are more efficient in the control of whitefly nymphs than adults.

As with the whitefly adults, all treatments presented little to none residual control of nymphs at the last evaluation (14 DAS). Even the treatments containing neonicotinoid insecticides (T2 and T6, with acetamiprid at 60 and $40 \mathrm{~g} \mathrm{ha}^{-1}$ respectively, and T7 with imidacloprid at a $210 \mathrm{~g} \mathrm{ha}^{-1}$ dose), which are known to provide some of the longest residual control effects among all chemical groups (Salgado, 2013), showed no control efficiency at 14 DAS. In fact, treatment T6 (acetamiprid + bifenthrin $40+40 \mathrm{~g} \mathrm{ha}^{-1}$ ) presented only $4.64 \%$ of average control efficiency for $B$. tabaci nymphs - the worst performance after treatment T3 (spiromesifene $144 \mathrm{~g} \mathrm{ha}^{-1}$ ), which provided $3.86 \%$ of average control and presented 81.5 nymphs leaflet ${ }^{-1}$ at the last evaluation (14 DAS). In the plants treated with $B$. bassiana (treatment T12), on the other hand, whitefly population was kept at 7.5 nymphs leaflet $^{-1}$ (see Table 2).

Despite being commonly used for the control of other sucking pests, such as stink bugs, these chemical insecticides seem to perform very poorly on the control of whitefly nymphs. While the high infestation level at the spray moment (45.6 nymphs leaflet ${ }^{-1}$ ) may be one of the reasons leading to such lack of control, this outcome can also be related to the intrinsic behavior and distribution of the whitefly nymphs along the tomato plants. Pozebon et al. (2018) stated that $B$. tabaci nymphs feeding on soybean plants concentrate mainly in the middle and lower thirds of the plants, on the abaxial side of the leaflets and in the middle and bottom parts of its surface. If such distribution pattern applies also for tomato plants, which is very likely, any flaw in the spray coverage could compromise the efficacy of the treatment, since the points of the plant canopy preferred by the nymphs are also the ones more difficult to be reached by the spray.

\subsection{Experiment II}

Whitefly infestation inside the greenhouse on Experiment II at the spray moment was at a lower level than on Experiment I, with an average of 2.7 adults leaflet $^{-1}$ and 10.0 nymphs leaflet $^{-1}$ (Table 3 ). As a consequence, the means of control efficiency for both whitefly adults and nymphs were overall higher on Experiment II, attesting the importance of an early spray at the beginning of the infestation. Control efficiency was also clearly enhanced by the second spray, carried out seven days after the first. The two last evaluations of adults (7 DA2S and 11 DA2S) presented control efficiencies equal to zero or very near it, as shown on Table 3; differently from Experiment I, however, this was a result of the non-occurrence of $B$. tabaci adults in all treatments, including the untreated control, signaling that the adult infestation had reached its end. 
Table 3. Mean number (M) of living adults and nymphs leaflet ${ }^{-1}$ and control efficiency (CE\%) of Bemisia tabaci adults and nymphs in response to the treatments sprayed on greenhouse tomatoes in Experiment II. São José do Hortêncio, RS, Brazil

\begin{tabular}{|c|c|c|c|c|c|c|c|c|c|c|c|c|}
\hline \multirow{2}{*}{ Treataments } & \multirow{2}{*}{$\begin{array}{l}\text { O DA1S }{ }^{1} \\
\text { M }\end{array}$} & \multicolumn{2}{|c|}{4 DA1S } & \multicolumn{2}{|c|}{7 DA1S } & \multicolumn{2}{|c|}{4 DA2S } & \multicolumn{2}{|c|}{7 DA2S } & \multicolumn{2}{|c|}{11 DA2S } & \multirow{2}{*}{$\begin{array}{l}\text { Mean } \\
\text { CE\% }\end{array}$} \\
\hline & & M & CE\% & M & CE\% & M & $\mathrm{CE} \%$ & $\mathbf{M}$ & CE\% & M & CE\% & \\
\hline \multicolumn{13}{|l|}{ Adults } \\
\hline Untreated control & 2.7 & $1.1 \mathrm{a}^{2}$ & - & $2.5 \mathrm{a}$ & - & $1.7 \mathrm{a}$ & - & $0.0 \mathrm{~b}$ & - & $0.0 \mathrm{a}$ & - & - \\
\hline Acetamiprid + pyriproxyfen & 2.7 & $0.8 \mathrm{a}$ & 27.27 & $0.6 \mathrm{~b}$ & 76.00 & $0.6 \mathrm{a}$ & 64.71 & $0.1 \mathrm{~b}$ & 0.00 & $0.0 \mathrm{a}$ & 0.00 & 55.99 \\
\hline Spiromesifene & 2.7 & $0.8 \mathrm{a}$ & 27.27 & $0.8 \mathrm{~b}$ & 68.00 & $0.9 \mathrm{a}$ & 47.06 & $0.1 \mathrm{~b}$ & 0.00 & $0.0 \mathrm{a}$ & 0.00 & 47.44 \\
\hline Cyantraniliprole & 2.7 & $0.5 \mathrm{a}$ & 54.55 & $0.9 \mathrm{~b}$ & 64.00 & $0.6 \mathrm{a}$ & 64.71 & $0.0 \mathrm{~b}$ & 0.00 & $0.0 \mathrm{a}$ & 0.00 & 61.08 \\
\hline Cyantraniliprole + lambda-cyhalothrin & 2.7 & $0.4 \mathrm{a}$ & 63.64 & $1.3 \mathrm{~b}$ & 48.00 & $0.3 \mathrm{a}$ & 82.35 & $0.0 \mathrm{~b}$ & 0.00 & $0.0 \mathrm{a}$ & 0.00 & 64.66 \\
\hline Acetamiprid + bifenthrin & 2.7 & $0.9 \mathrm{a}$ & 18.18 & $1.3 \mathrm{~b}$ & 48.00 & $0.9 \mathrm{a}$ & 47.06 & $0.0 \mathrm{~b}$ & 0.00 & $0.0 \mathrm{a}$ & 0.00 & 37.75 \\
\hline Imidacloprid & 2.7 & $0.4 \mathrm{a}$ & 63.64 & $1.1 \mathrm{~b}$ & 56.00 & $0.5 \mathrm{a}$ & 70.59 & $0.2 \mathrm{~b}$ & 0.00 & $0.0 \mathrm{a}$ & 0.00 & 63.41 \\
\hline E-coda-oil K & 2.7 & $1.0 \mathrm{a}$ & 9.09 & $2.7 \mathrm{a}$ & 0.00 & $1.1 \mathrm{a}$ & 35.29 & $0.4 \mathrm{~b}$ & 0.00 & $0.0 \mathrm{a}$ & 0.00 & 14.80 \\
\hline Citronella extract & 2.7 & $1.1 \mathrm{a}$ & 0.00 & $3.3 \mathrm{a}$ & 0.00 & $1.0 \mathrm{a}$ & 41.18 & $0.5 \mathrm{a}$ & 0.00 & $0.0 \mathrm{a}$ & 0.00 & 13.73 \\
\hline Embrapa formula & 2.7 & $0.6 \mathrm{a}$ & 45.45 & $1.5 \mathrm{~b}$ & 40.00 & $3.2 \mathrm{a}$ & 0.00 & $0.0 \mathrm{a}$ & 0.00 & $0.0 \mathrm{a}$ & 0.00 & 28.48 \\
\hline Pyrolignous extract & 2.7 & $0.2 \mathrm{a}$ & 81.82 & $1.9 \mathrm{~b}$ & 24.00 & $1.0 \mathrm{a}$ & 41.18 & $0.0 \mathrm{~b}$ & 0.00 & $0.0 \mathrm{a}$ & 0.00 & 49.00 \\
\hline Beauveria bassiana & 2.7 & $1.1 \mathrm{a}$ & 0.00 & $1.7 \mathrm{a}$ & 32.00 & $1.6 \mathrm{a}$ & 5.88 & $0.0 \mathrm{~b}$ & 0.00 & $0.0 \mathrm{a}$ & 0.00 & 12.63 \\
\hline $\mathrm{CV}(\%)^{3}$ & & 74.84 & - & 70.96 & - & 72.19 & - & 152.92 & - & 0.00 & - & - \\
\hline \multicolumn{13}{|l|}{ Nymphs } \\
\hline Untreated control & 10.0 & $3.5 \mathrm{~b}$ & - & $56.9 \mathrm{a}$ & - & $34.4 \mathrm{a}$ & - & $42.1 \mathrm{a}$ & - & $29.5 \mathrm{a}$ & - & - \\
\hline Acetamiprid + pyriproxyfen & 10.0 & $1.3 \mathrm{~b}$ & 62.86 & $27.1 \mathrm{~b}$ & 52.37 & $10.8 \mathrm{~b}$ & 68.60 & $11.7 \mathrm{c}$ & 72.21 & $20.0 \mathrm{~b}$ & 32.20 & 57.65 \\
\hline Spiromesifene & 10.0 & $11.6 \mathrm{a}$ & 0.00 & $64.1 \mathrm{a}$ & 0.00 & $15.4 \mathrm{~b}$ & 55.23 & $7.3 \mathrm{c}$ & 82.66 & $31.5 \mathrm{a}$ & 0.00 & 27.58 \\
\hline Cyantraniliprole & 10.0 & $15.5 \mathrm{a}$ & 0.00 & 79.6 a & 0.00 & $32.1 \mathrm{a}$ & 6.69 & $27.7 \mathrm{~b}$ & 34.20 & $27.3 \mathrm{a}$ & 7.46 & 9.67 \\
\hline Cyantraniliprole + lambda-cyhalothrin & 10.0 & $7.7 \mathrm{~b}$ & 0.00 & $22.9 \mathrm{~b}$ & 59.75 & $13.0 \mathrm{~b}$ & 62.21 & $2.6 \mathrm{c}$ & 93.82 & $23.1 \mathrm{a}$ & 21.69 & 47.50 \\
\hline Acetamiprid + bifenthrin & 10.0 & $11.6 \mathrm{a}$ & 0.00 & $16.3 \mathrm{~b}$ & 71.35 & $6.9 \mathrm{~b}$ & 79.94 & $12.1 \mathrm{c}$ & 71.26 & $17.2 \mathrm{~b}$ & 41.69 & 52.85 \\
\hline Imidacloprid & 10.0 & $15.3 \mathrm{a}$ & 0.00 & $27.2 \mathrm{~b}$ & 52.20 & $10.2 \mathrm{~b}$ & 70.35 & $12.6 \mathrm{c}$ & 70.07 & $35.2 \mathrm{a}$ & 0.00 & 38.52 \\
\hline E-coda-oil K & 10.0 & $27.7 \mathrm{a}$ & 0.00 & $75.8 \mathrm{a}$ & 0.00 & $10.2 \mathrm{~b}$ & 70.35 & $13.9 \mathrm{c}$ & 66.98 & $30.4 \mathrm{a}$ & 0.00 & 27.47 \\
\hline Citronella extract & 10.0 & $13.9 \mathrm{a}$ & 0.00 & $36.8 \mathrm{a}$ & 35.33 & $9.9 \mathrm{~b}$ & 71.22 & $10.3 \mathrm{c}$ & 75.53 & $9.5 \mathrm{~b}$ & 67.80 & 49.98 \\
\hline Embrapa formula & 10.0 & $1.0 \mathrm{~b}$ & 71.43 & $12.5 \mathrm{c}$ & 78.03 & $9.3 \mathrm{~b}$ & 72.97 & $9.1 \mathrm{c}$ & 78.38 & $11.6 \mathrm{~b}$ & 60.68 & 72.30 \\
\hline Pyrolignous extract & 10.0 & $5.1 \mathrm{~b}$ & 0.00 & $12.3 \mathrm{c}$ & 78.38 & $10.6 \mathrm{~b}$ & 69.19 & $5.7 \mathrm{c}$ & 86.46 & $15.2 \mathrm{~b}$ & 48.47 & 56.50 \\
\hline Beauveria bassiana & 10.0 & $8.1 \mathrm{~b}$ & 0.00 & $7.9 \mathrm{c}$ & 86.12 & $15.3 \mathrm{~b}$ & 55.52 & $6.5 \mathrm{c}$ & 84.56 & $15.0 \mathrm{~b}$ & 49.15 & 55.07 \\
\hline $\mathrm{CV}(\%)^{3}$ & - & 67.61 & - & 47.38 & - & 106.09 & - & 103.49 & - & 71.08 & - & - \\
\hline
\end{tabular}

Note. ${ }^{1} \mathrm{DAS}=$ Days after spraying. ${ }^{2}$ Means followed by the same letter do not differ among themselves by the Scott-Knott test $(\mathrm{P} \leq 0.05) .{ }^{3} \mathrm{CV}(\%)=$ Coefficient of variation.

The highest reductions of $B$. tabaci adults were obtained by treatments $\mathrm{T} 5$ (cyantraniliprole + lambda-cyhalothrin $50+30 \mathrm{~g} \mathrm{ha}^{-1}$ ) and T7 (imidacloprid $210 \mathrm{~g} \mathrm{ha}^{-1}$ ), with $65 \%$ and $63 \%$ of average control efficiency, respectively; population density on these treatments was kept under 1.3 adults leaflet ${ }^{-1}$. Treatment T12 (Beauveria bassiana $16 \mathrm{~g} \mathrm{ha}^{-1}$ ), on the other hand, presented the worst performance, reducing the population of whitefly adults in $12 \%$, in average. Considering the high adult mortality provided by treatment T12 on Experiment I, it can be assumed that a lower population of whitefly adults provides less means of dispersion for the spores of $B$. bassiana, which are also less effective in the control of $B$. tabaci adults than nymphs (Azevedo, Guimarães, Braga Sobrinho, \& Lima, 2005). Conversevely, all chemical insecticides presented higher means of control efficiency on Experiment II than on Experiment I, which is probably related to the use of two sprays instead of one, starting at the beginning of the infestation.

Regarding the control of $B$. tabaci nymphs, the bioinsecticides were overall superior than the chemicals, agreeing with the results found on Experiment 1 . The highest nymph mortality was obtained by the treatment T10 or Embrapa formula ( $0.5 \%$ flaxseed oil $+0.5 \%$ neutral detergent $+0.3 \%$ sodium bicarbonate), with an average reduction of $72 \%$ in the nymph population and fast knockdown effect after the sprays. The plants treated with this formula did not present more than 12.5 nymphs leaflet ${ }^{-1}$ in any of the evaluations, while population density in the other treatments reached as high as 80 nymphs leaflet $^{-1}$ (treatment T4 at 7 DA1S; see Table 3 ). The Embrapa formula is based on home-made treatments used by organic growers in the Vale do Caí region, and though not very efficient on situations of high infestation, such as on Experiment 1, seems to perform satisfactorily on lower whitefly populations. 
As on Experiment I, treatment T12 (Beauveria bassiana $16 \mathrm{~g} \mathrm{ha}^{-1}$ ) kept nymph population at the lowest levels, reaching $86 \%$ of control efficiency at 7 DA1S with a population density of 8 nymphs leaflet ${ }^{-1}$; for comparison, at the same evaluation the plants treated with cyantraniliprole $50 \mathrm{~g} \mathrm{ha}^{-1}$ (treatment T4) presented an infestation of 80 nymphs leaflet ${ }^{-1}$. All treatments except T4 (cyantraniliprole $50 \mathrm{~kg} \mathrm{ha}^{-1}$ ) provided their highest control means after the second spray (7 DA2S), ranging from 67\% (treatment T8) to $94 \%$ (treatment T5) of nymph mortality at this evaluation. These results denote the importance of sequential sprays in order to enhance control efficiency, regardless of the insecticide used.

Besides preventing direct damage, keeping the whitefly infesting population at the lowest possible level is also a key factor in avoiding damages due to virus transmission. B. tabaci serves as a main vector for the circulative begomovirus Tomato yellow leaf curls virus (TYLCV), which is known to directly manipulate the settling, probing and feeding behavior of the whitefly in a way that enhances virus transmission efficiency and spread (Moreno-Delafuente, Garzo, Moreno, \& Fereres, 2013). Additionally, the interaction between begomoviruses and $B$. tabaci have evolved through millennia to be mutually beneficial for both virus and vector (Czosnek \& Ghanim, 2012), since the whitefly adult feeds more efficiently after acquiring the virus (Maluta, Garzo, Moreno, Lopes, \& Fereres, 2014) and prefer to lay eggs on virus-infected than on non-infected tomato plants (Fereres et al., 2016).

\subsection{Combined Analysis}

By comparing the results obtained from Experiments I and II, considering its different infestation levels and spraying programs, it becomes clear that sequential sprays beginning at the infestation onset are a key factor for the control of B. tabaci. The lack of an economic injury level for whitefly on tomato crops may represent a complication for monitoring and decision-making, but the works conducted on other crops (e.g. watermelon; Lima et al., 2018) and the evidence found on the present study suggest that the threshold for B. tabaci control must be set at a very early stage of the infestation, in order to ensure control efficiency of both chemical and biological insecticides.

While the final means of control efficiency stayed much below the level considered ideal $(\geq 80.0 \%)$, as shown on Figure 1, the vanishing of whitefly adults on certain evaluations of Experiment II and the overall lack of control in Experiment I resulted in an overeduction of the average means, which do not represent the subtleties of behavior in the different treatments; thus, a much better understanding is obtained by focusing on each individual evaluation. Although tomato plants are not grown in open field in the region, the natural occurrence of infestation inside the greenhouses points to a link with field populations in other crops; consequently, the drastic reduction in the population of whitefly adults (including the untreated control) at the last evaluations in Experiment II (see Table 3) might be associated with unfavorable climatic conditions during this period such as higher relative air humidity and lower mean temperatures (see Supplementary Table 1), which are detrimental to whitefly population and its spread (Sharma et al., 2013; Sharma, Maqbool, Jamwal, Srivastava, \& Sharma, 2017). Nonetheless, the combined analysis of control efficiency means (Table 4) shows that the two experiments agreed on their main outcomes, despite being carried out under different infestation conditions. 


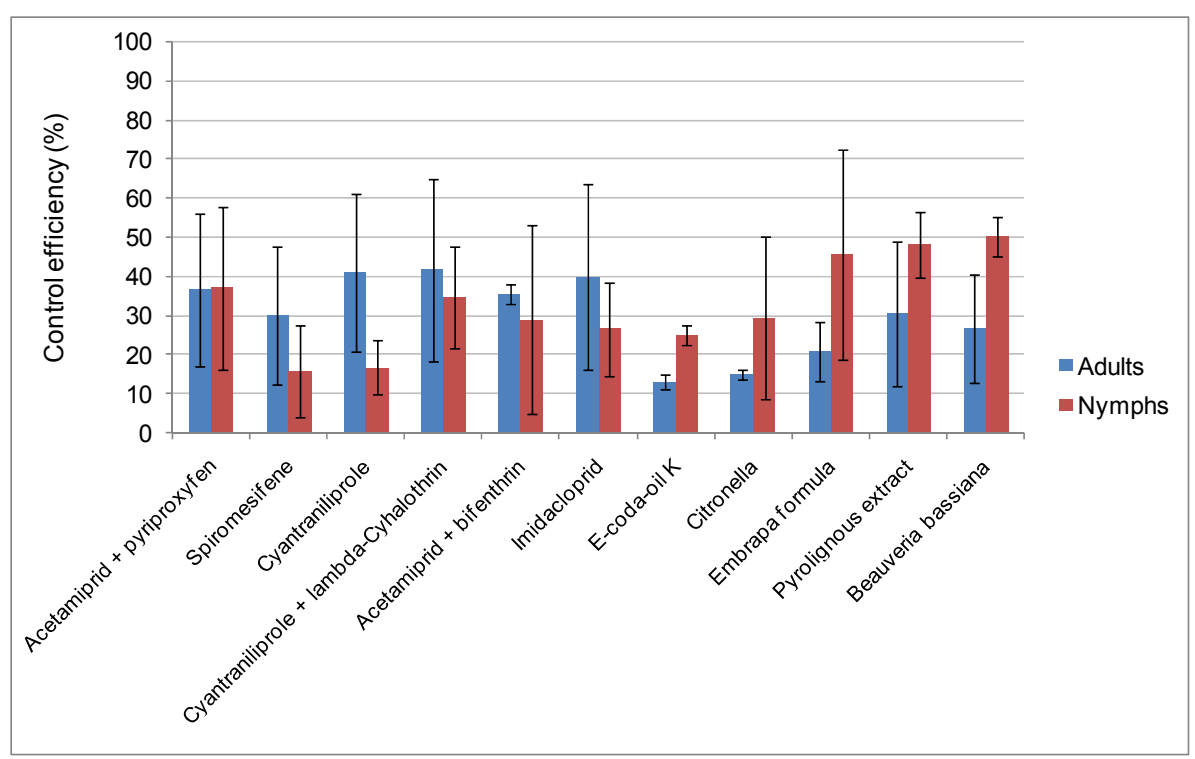

Figure 1. Average means and standard deviation for control efficiency (CE\%) of Bemisia tabaci adults and nymphs in response to the treatments sprayed on greenhouse tomatoes. São José do Hortêncio, RS, Brazil

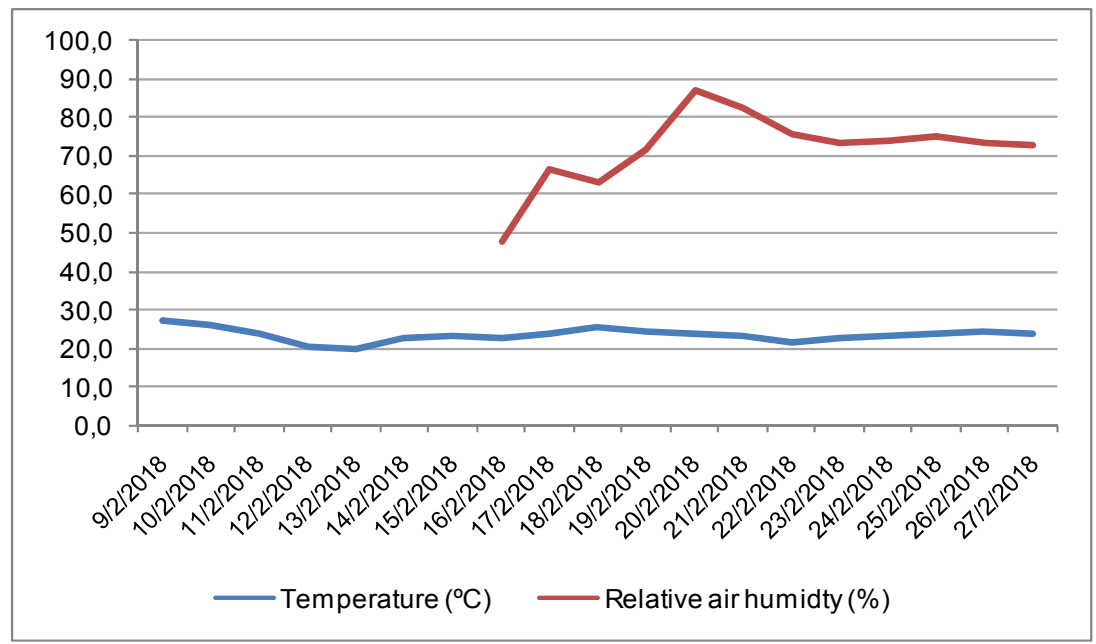

Supplementary Figure 1 . Average temperature $\left({ }^{\circ} \mathrm{C}\right)$ and relative air humidity $(\%)$ registered on each day during the conduction of the experiments, in the meteorological station of Novo Hamburgo, RS, Brazil. Relative air humidy prior to day 16/02/2018 unavailable. Data provided by INMET (National Meteorological Institute),

\section{RS, Brazil}


Table 4. Means of control efficiency (CE\%) of Bemisia tabaci adults and nymphs in response to the treatments sprayed on greenhouse tomatoes in Experiment I and Experiment II, and in average means. São José do Hortêncio, RS, Brazil

\begin{tabular}{|c|c|c|c|}
\hline Treataments & Experiment I (CE\%) & Experiment II (CE\%) & Average mean (CE\%) \\
\hline \multicolumn{4}{|l|}{ Adults } \\
\hline Untreated control & - & - & - \\
\hline Acetamiprid + pyriproxyfen & 17.07 & 55.99 & 36.53 \\
\hline Spiromesifene & 12.52 & 47.44 & 29.98 \\
\hline Cyantraniliprole & 20.79 & 61.08 & 40.94 \\
\hline Cyantraniliprole + lambda-cyhalothrin & 18.40 & 64.66 & 41.53 \\
\hline Acetamiprid + bifenthrin & 32.84 & 37.75 & 35.30 \\
\hline Imidacloprid & 16.18 & 63.41 & 39.80 \\
\hline E-coda-oil K & 11.03 & 14.80 & 12.92 \\
\hline Citronella extract & 16.31 & 13.73 & 15.02 \\
\hline Embrapa formula & 13.24 & 28.48 & 20.86 \\
\hline Pyrolignous extract & 11.76 & 49.00 & 30.38 \\
\hline Beauveria bassiana & 40.46 & 12.63 & 26.55 \\
\hline \multicolumn{4}{|l|}{ Nymphs } \\
\hline Untreated control & - & - & - \\
\hline Acetamiprid + pyriproxyfen & 16.19 & 57.65 & 36.92 \\
\hline Spiromesifene & 3.86 & 27.58 & 15.72 \\
\hline Cyantraniliprole & 23.82 & 9.67 & 16.75 \\
\hline Cyantraniliprole + lambda-cyhalothrin & 21.54 & 47.50 & 34.52 \\
\hline Acetamiprid + bifenthrin & 4.64 & 52.85 & 28.75 \\
\hline Imidacloprid & 14.36 & 38.52 & 26.44 \\
\hline E-coda-oil K & 22.63 & 27.47 & 25.05 \\
\hline Citronella extract & 8.46 & 49.98 & 29.22 \\
\hline Embrapa formula & 18.50 & 72.30 & 45.40 \\
\hline Pyrolignous extract & 39.71 & 56.50 & 48.11 \\
\hline Beauveria bassiana & 45.29 & 55.07 & 50.18 \\
\hline
\end{tabular}

The chemical insecticides were overall superior than the bioinsecticides in the control of whitefly adults, with the highest average means being obtained by the treatments T5 (cyantraniliprole + lambda-cyhalothrin $50+30 \mathrm{~g} \mathrm{ha}^{-1}$ ), T4 (cyantraniliprole $50 \mathrm{~g} \mathrm{ha}^{-1}$ ) and T7 (imidacloprid $210 \mathrm{~g} \mathrm{ha}^{-1}$ ), in that order. Conversevely, the bioinsectides presented a superior performance in the control of whitefly nymphs, with the highest average means being obtained by the treatments T12 (Beauveria bassiana $16 \mathrm{~g} \mathrm{ha}^{-1}$ ), T11 (Pyroligneous extract) and T10 (Embrapa formula), in that order (see Table 4). Therefore, cyantraniliprole + lambda-cyhalothrin $\left(50+30 \mathrm{~g} \mathrm{ha}^{-1}\right)$ is the most efficient treatment for the control of $B$. tabaci adults on tomato plants (keeping the infestation level under 1.3 adults leaflet ${ }^{-1}$ ), while the bioinsecticide Embrapa formula is the most efficient for the control of $B$. tabaci nymphs (keeping the infestation level under 12.5 nymphs leaflet $^{-1}$ ).

This outcome may be a result of the differences in behavior and dispersion of B. tabaci nymphs and adults. Chemical insecticides affect the insect's body by direct contact or ingestion. Assuming that whitefly adults prefer to feed and oviposit in the upper parts of the tomato plants, as observed in cucumber (Moura et al., 2003) and soybean plants (Pozebon et al., 2018; Czepack et al., 2018), they are more likely to be direct reached by the insecticide spray, or to ingest its active ingredient through sap sucking. Whitefly nymphs, on the other hand, are sessile and stay sheltered in the abaxial side of the leaflets in the middle and lower thirds of the plants, thus avoiding direct contact with the chemical spray as well as its ingestion, since systemic insecticides are translocated mainly upwards from older to younger leaves (Buchholz \& Nauen, 2002) and the lower third of the canopy is a region of difficult access by the spray. Therefore, $B$. tabaci nymphs are more likely to be affected by insecticides with alternative modes of action and contamination, such as $B$. bassiana spores, or containing ingredients with adherence properties, such as the flaxseed oil in the Embrapa formula.

Entomopathogenic fungi such as $B$. bassiana are easy to apply and present no risk to human health or natural enemies (Vestergaard et al., 2003; Zimmerman, 2008); however, fungi are slow acting compared to chemical insecticides and incompatible with most fungicides, besides being relatively expensive and highly dependent on environmental conditions and good spray coverage (Vidal et al., 2003). Thus, a decision to spray chemical or 
bioinsecticides should not be based only on control efficacy, since other factors such as infestation level and control costs have to be considered.

In the current agricultural scenario, the use of chemical and bioinsecticides remains the most efficient and economically viable control strategy for $B$. tabaci on tomato crops. However, the increasing control failures and growing occurrence of resistant populations make clear the necessity of developing alternative methods inside the integrated pest management (IPM) and integrated resistance management (IRM) approaches for this pest. Accordingly, further studies should focus on the establishment of an economic injury level for whitefly on tomato crops, which constitutes the basis for any monitoring and control program of major agricultural pests.

\section{References}

Azevedo, F. R., Guimarães, J. A., Braga Sobrinho, R., \& Lima, M. A. A. (2005). Eficiência de produtos naturais para o controle de Bemisia tabaci Biótipo B (Hemiptera: Aleyrodidae) em meloeiro. Arquivos do Instituto Biológico, 72(1), 73-79.

Basu, A. N. (1995). Bemisia tabaci (Gennadius): Crop pest and principal whitefly vector of plant viruses. New Delhi, India: Oxford \& IBH.

Bernardi, L. E. (2016). Bemisia tabaci biótipo A, B, Q? Lageado, RS, Brazil: Emater/RS-ASCAR.

Buchholz, A., \& Nauen, R. (2002). Translocation and translaminar bioavailability of two neonicotinoid insecticides after foliar application to cabbage and cotton. Pest Management Science, 58, 10-16. https://doi.org/10.1002/ps.401

Byrne, D. N., \& Bellows Junior, T. S. (1991). Whitefly biology. Annual Review of Entomology, 36, 431-457. https://doi.org/10.1146/annurev.en.36.010191.002243

Cohen, S., \& Antignus, Y. (1994). Tomato yellow leaf curl virus, a whitefly-borne geminivirus of tomatoes. Advances in Disease Vector Research, 10, 259-288. https://doi.org/10.1007/978-1-4612-2590-4_10

Czepak, C., Coelho, A. S. G., Rezende, J. M., Nunes, M. L. S., Weber, I. D., Silvério, R. F., \& Albernaz-Godinho, K. C. (2018). Bemisia tabaci MEAM1 population surveys in soybean cultivation. Entomologia Experimentalis et Applicata, 166, 215-223. https://doi.org/10.1111/eea.12656

Czosnek, H., \& Ghanim, M. (2012). Back to basics: Are begomoviruses whitefly pathogens? Journal of Integrative Agriculture, 11(2), 225-234. https://doi.org/10.1016/S2095-3119(12)60007-0

De Barro, P. J., Driver, F., Trueman, J. W. H., \& Curran, J. (2000). Phylogenetic relationships of world populations of Bemisia tabaci (Gennadius) using ribosomal ITS1. Molecular Phylogenetics and Evolution, 16(1), 29-36. https://doi.org/10.1006/mpev.1999.0768

De Barro, P. J., Liu, S. S., Boykin, L. M., \& Dinsdale, A. B. (2011). Bemisia tabaci: A statement of species status. Annual Review of Entomology, 56, 1-19. https://doi.org/10.1146/annurev-ento-112408-085504

Emater/RS-ASCAR. (2017). Regional-Lajeado. Retrieved from http://www.emater.tche.br/site/a-emater/aprese ntacao.php\#.XDzAxtQrKt8

Fauquet, C. M., Briddon, R. W., Brown, J. K., Moriones, E., Stanley, J., Zerbini, M., \& Zhou, X. (2008). Geminivirus strain demarcation and nomenclature. Archives of Virology, 153, 783-821. https://doi.org/ 10.1007/s00705-008-0037-6

Fereres, A., Peñaflor, M. F. G. V., Favaro, C. F., Azevedo, K. E. X., Landi, C. H., Maluta, N. K. P., ... Lopes, J. R. S. (2016). Tomato infection by whitefly-transmitted circulative and non-circulative viruses induce contrasting changes in plant volatiles and vector behavior. Viruses, 8, 225. https://doi.org/10.3390/v8080225

Groden, E. (1999). Proceedings of the New England vegetable and berry growers conference and trade show. Sturbridge, MA.

Hirose, E., Batista, A. S., \& Silva, M. S. (2015). Correlação da ocorrência de fumagina em soja com a população de ninfas de mosca-branca Bemisia tabaci (Hemiptera: Aleyrodidae). Embrapa Soja, Cuiabá, MT: VI Congresso Brasileiro de Soja.

Jones, D. (2003). Plant viruses transmitted by whiteflies. European Journal of Plant Pathology, 109, 197-221. https://doi.org/10.1023/A:1022846630513

Lima, C. H. de O., Sarmento, R. A., Pereira, P. S., Ribeiro, A. V., Souza, D. J., \& Picanço, M. C. (2018). Economic injury levels and sequential sampling plans for control decision-making systems of Bemisia tabaci biotype B adults in watermelon crops. Pest Management Science. https://doi.org/10.1002/ps.5207 
Maluta, N. K. P., Garzo, E., Moreno, A., Lopes, J. R. S., \& Fereres, A. (2014). Tomato yellow leaf curl virus benefits population growth of the Q biotype of Bemisia tabaci (Gennadius) (Hemiptera: Aleyrodidae). Neotropical Entomology, 43(4), 385-392. https://doi.org/10.1007/s13744-014-0223-z

Moreno-Delafuente, A., Garzo, E., Moreno, A., \& Fereres, A. (2013). A plant virus manipulates the behavior of its whitefly vector to enhance its transmission efficiency and spread. PLoS One, 8(4), e61543. https://doi.org/10.1371/journal.pone.0061543

Moura, M. F., Picanço, M. C., Silva, E. M., Guedes, R. N. C., \& Pereira, J. L. (2003). Plano de amostragem do biótipo B de Bemisia tabaci na cultura do pepino. Pesquisa Agropecuária Brasileira, 38, 1357-1363. https://doi.org/10.1590/S0100-204X2003001200001

Naranjo, S. E., Chu, C. C., \& Henneberry, T. J. (1996). Economic injury levels for Bemisia tabaci (Homoptera: Aleyrodidae) in cotton: impact of crop price, control costs, and efficacy of control. Crop Protection, 15(8), 779-788. https://doi.org/10.1016/S0261-2194(96)00061-0

Pozebon, H., Cargnelutti Filho, A., Guedes, J. V. C., Ferreira, D. R., Marques, R. P., Bevilaqua, J. G., ... Arnemann, J. A. (2018). Bemisia tabaci (Gennadius, 1889) on soybean plants: Vertical distribution and on leaflets. Entomologia Experimentalis et Applicata, in press.

Rosa, D. O. (2017). Diagnóstico do uso e do manejo de agrotóxicos na olericultura em propriedades de agricultura familiar no municipio de Feliz. Universidade Federal de Santa Maria, Santa Maria, Brazil.

Salgado, V. L. (2013). BASF Insecticide Mode of Action Technical Training Manual. Retrieved from https://www.researchgate.net/publication/275959530_BASF_Insecticide_Mode_of_Action_Technical_Trai ning_Manual

Santos, J. P. (2008). Principais insetos-praga e seu controle. In S. Mueller, A. F. Wamser, W. F. Becker, \& J. P. Santos (Eds.), Indicações técnicas para o tomateiro tutorado na região do Alto Vale do Rio do Peixe (pp. 40-60). Florianópolis, SC, Brazil: Epagri.

Sharma, D., Maqbool, A., Ahmad, H., Srivastava, K., Kumar, M., \& Jamwal, V. V. S. (2013). Effect of meteorological factors on the population dynamics of insect pests of tomato. Vegetable Science, 40(1), 90-92.

Sharma, D., Maqbool, A., Jamwal, V.V.S., Srivastava, K., \& Sharma, A. (2017). Seasonal dynamics and management of whitefly (Bemesia tabaci Genn.) in tomato (Solanum esculentum Mill.). Brazilian Archives of Biology and Technology, 60, e17160456. https://doi.org/10.1590/1678-4324-2017160456

Vestergaard, S., Cherry, A., Keller, S., \& Goettel, M. (2003). Safety of hyphomycete fungi as microbial control agents. In H. M. T. Hokkanen, \& A. E. Hajek (Eds.), Environmental Impacts of Microbial Insecticides: Needs and Methods for Risk Assessment (pp. 35-62). The Netherlands, Dordrecht: Kluwer Academic Publisher. https://doi.org/10.1007/978-94-017-1441-9

Vidal, C., Fargues, J., Rougier, M., \& Smits, N. (2003). Effect of air humidity on the infection potential of hyphomycetous fungi as mycoinsecticides for Trialeurodes vaporariorum. Biocontrol Science and Technology, 13, 183-198. https://doi.org/10.1080/0958315021000073457

Villas-Bôas, G. L., França, F. H., Ávila, A. C. de, \& Bezerra, I. C. (1997). Manejo integrado da mosca-branca Bemisia argentifolii. Brasília, DF, Brazil: Embrapa Hortaliças.

Zimmerman, G. (2008). The entomopathogenic fungi Isaria farinosa (formerly Paecilomyces farinosus) and the Isaria fumosorosea species complex (formerly Paecilomyces fumosoroseus): Biology, ecology and use in biological control. Biocontrol Science and Technology, 18, 865-901. https://doi.org/10.1080/095831508 02471812

\section{Copyrights}

Copyright for this article is retained by the author(s), with first publication rights granted to the journal.

This is an open-access article distributed under the terms and conditions of the Creative Commons Attribution license (http://creativecommons.org/licenses/by/4.0/). 